\title{
Akibat Hukum Pembatasan Asas Kebebasan Berkontrak Dalam Permen Agraria Dan Tata Ruang Nomor 29 Tahun 2016*
}

\author{
Oleh \\ I Gede Yudi Arsawan** \\ I Gede Yusa** \\ Program Kekhususan Hukum Bisnis Fakultas Hukum \\ Universitas Udayana
}

\begin{abstract}
ABSTRAK
Masyarakat dunia kerapkali berpergian dari suatu negara ke negara lain dengan tujuan berbeda-beda, ada yang memiliki tujuan untuk sekadar berwisata dan ada juga yang bertujuan untuk bekerja. Ada yang berasal dari negara lain kemudian berpindah dan menetap di Indonesia untuk jangka waktu yang lama, sehubungan dengan itu mereka juga membutuhkan tempat tinggal sebagai tempat untuk beristirahat serta untuk melindungi diri pada saat di luar jam kerja. Mereka yang berasal dari negara lain disebut sebagai orang asing. Orang asing juga dapat memiliki rumah untuk tempat tinggal atau hunian dengan Hak Pakai, namun dalam Permen ATR Nomor 29 Tahun 2016 terdapat aturan yang menyebabkan terjadinya pembatasan terhadap asas kebebasan berkontrak dari pihak-pihak yang akan membuat kesepakatan berkaitan dengan pengalihan Hak Pakai. Dalam tulisan ini akan diuraikan mengenai bagaimana pembatasan asas kebebasan berkontrak dalam Permen ATR Nomor 29 Tahun 2016 serta apa akibat hukum dengan adanya pembatasan tersebut. Penelitian ini menggunakan metode penelitian hukum normatif dengan pendekatan perundangundangan yang mengkaji peraturan Permen ATR Nomor 29 Tahun 2016 serta pasal 1338 Burgerlijk Wetboek (KUHPer). Hasil penelitian ini menemukan bahwa dengan adanya pembatasan Asas Kebebasan

\footnotetext{
*Akibat Hukum Pembatasan Asas Kebebasan Berkontrak Dalam Permen ATR Nomor 29 Tahun 2016 merupakan karya ilmiah di luar ringkasan skripsi.

${ }^{* *}$ I Gede Yudi Arsawan adalah penulis pertama dalam karya ilmiah ini yang merupakan mahasiswa Fakultas Hukum Universitas Udayana.

${ }^{* * *}$ I Gede Yusa adalah dosen pengajar Fakultas Hukum Universitas Udayana,gedeyusa@rocketmail.com.
} 
Berkontrak Dalam Permen ATR Nomor 29 Tahun 2016 dapat menimbulkan terjadinya penyelundupan hukum karena para pihak yaitu penjual dan pembeli bisa mengambil cara mudah yang sifatnya sebagai penyamaran, seperti misalnya dengan memalsukan harga transaksi yang sebenarnya dengan yang tercantum dalam perjanjian atau hingga melakukan perbuatan nominee agar mempermudah proses transaksi yang membuat timbulnya penafsiran adanya iktikad tidak baik diantara para pihak.

\title{
Kata Kunci : Orang Asing, Kebebasan Berkontrak, Perjanjian.
}

\begin{abstract}
The world community often travels from one country to another with different objectives, some have a purpose to just travel and some aim to work. Some from other countries then moved and settled in Indonesia for a long period of time, in connection with that they also needed a place to live as a place to rest and to protect themselves after working hours. Foreigners can also have a home for a place to live or occupy with Right to Use. This provision can certainly provide a sense of security and comfort for foreigners to settle in Indonesia because they can have their own place of residence, but in Permen ATR Number 29 Year 2016 there is a rule that cause restrictions on the principle of freedom of contract from those who will make agreements relating to the transfer of Right to Use. This paper will describe how is the limit of the freedom of contract principle in Permen ATR Number 29 Year 2016 and what are the consequences of the law in the presence of these restrictions. This research uses normative legal research methods with legislative approaches by reviewing the Regulation of Permen ATR Number 29 Year 2016 as well as article 1338 Burgerlijk Wetboek. The results of this research found that with the limitation of the Principle of Freedom of Contracting in Permen ATR Number 29 Year 2016 can lead to legal smuggling because the parties, namely sellers and buyers, may take easy ways as disguises, such as by falsifying the actual transaction price with those listed in the agreement or to carry out a nominee act in order to facilitate the transaction process which makes the interpretation of the existence of bad intentions between the parties arise.
\end{abstract}

Key Words : Foreigners, Freedom of Contract, Agreement. 


\section{PENDAHULUAN}

\subsection{Latar Belakang}

Dalam era globalisasi sekarang ini, masyarakat dunia kerapkali berpergian dari suatu negara ke negara lain dengan tujuan berbeda-beda, ada yang memiliki tujuan untuk sekadar berwisata dan ada juga yang bertujuan untuk bekerja. Ada yang berasal dari negara lain kemudian berpindah dan menetap di Indonesia untuk jangka waktu yang lama, sehubungan dengan itu mereka juga membutuhkan tempat tinggal sebagai tempat untuk beristirahat serta untuk melindungi diri pada saat di luar jam kerja.

Mereka yang menetap di Indonesia dan bukan merupakan Warga Negara Indonesia (WNI) disebut sebagai Warga Negara Asing (WNA) atau orang asing. Pasal 1 angka 1 PP Nomor 103 Tahun 2015 menjelaskan yang pada intinya bahwa orang asing adalah orang bukan WNI yang keberadaannya memberikan manfaat atau berinvestasi di Indonesia. Orang asing yang memilih tinggal di Indonesia dapat memberikan dampak positif bagi perkembangan perekonomian di Indonesia salah satunya dengan melakukan investasi di Indonesia. ${ }^{1}$

PP Nomor 103 Tahun 2015 mengatur bahwa orang asing diberikan kesempatan memiliki tempat tinggal dengan Hak Pakai. Ketentuan ini tentunya memberikan rasa aman dan nyaman bagi orang asing untuk menetap di Indonesia karena dapat memiliki tempat tinggal sendiri.

Hak untuk memiliki tempat tinggal sebenarnya juga merupakan Hak Asasi Manusia yang sudah seharusnya dipenuhi

${ }^{1}$ Made Utami Jayanti, 2018, Pengaturan Perjanjian Pengikatan Jual Beli Atas Rumah Tempat Tinggal Oleh Warga Negara Asing Dengan Berlakunya Peraturan Menteri Agraria Dan Tata Ruang Nomor 29 Tahun 2016, Acta Comitas Vol. 3 No. 2, h. 353. 
oleh seluruh negara termasuk Indonesia. Pasal 11 ayat (1) International Covenant On Economic, Social And Cultural Rights yang juga sudah diratifikasi oleh negara Indonesia dengan UU Nomor 11 Tahun 2005 mengatur bahwa setiap orang berhak akan suatu standar penghidupan yang layak untuk diri sendiri dan keluarganya yang mana hak tersebut juga termasuk hak atas perumahan. Dengan adanya PP Nomor 103 Tahun 2015 tersebut maka Indonesia dapat dikatakan telah memenuhi kewajibannya untuk memberikan hak atas perumahan bagi setiap orang khususnya orang asing yang sedang menetap di wilayahnya.

Orang asing hanya bisa mendapatkan tempat tinggal dengan Hak Pakai sebagaimana ditentukan dalam Pasal 41 ayat (1) UUPA dimana Hak Pakai adalah hak untuk dapat mempergunakan atau melakukan pungutan terhadap hasil dari tanah yang dikuasai oleh Negara atau milik orang lain, yang memberi wewenang serta ditentukan oleh suatu keputusan pemberian terhadap hal tersebut oleh pejabat yang memiliki wewenang atau melalui perjanjian bersama pemilik tanah, tidak merupakan perjanjian sewa menyewa atau pengolahan tanah dan tidak bertentangan dengan peraturan. Setiap orang asing yang ingin memiliki tempat tinggal dengan hak pakai harus melalui prosedur yang sudah ditentukan dalam aturan yang berlaku. Di Indonesia, secara umum sebelum orang asing membeli objek hak atas tanah, setelah mereka memilih objeknya maka akan membuat kesepakatan dengan pemilik daripada hak atas tanah yang bersangkutan. Pengaturan lebih lanjut tentang pengalihan hak atas pemilikan tempat tinggal oleh orang asing yang tinggal di Indonesia diatur melalui Peraturan Menteri Agraria dan Tata Ruang/Kepala Badan Pertanahan Nasional Republik Indonesia Nomor 29 Tahun 2016 (selanjutnya disebut Permen ATR Nomor 29 Tahun 2016), dalam Permen ATR Nomor 29 Tahun 2016 tersebut 
terdapat aturan yang menyebabkan terjadinya pembatasan terhadap asas kebebasan berkontrak sebagaimana diatur dalam pasal 1338 Kitab Undang-Undang Hukum Perdata dari pihak-pihak yang akan membuat kesepakatan dan dapat menimbulkan akibat hukum yang seharusnya tidak timbul di antara para pihak. Dalam tulisan ini akan diuraikan mengenai bagaimana pembatasan asas kebebasan berkontrak dalam Permen ATR Nomor 29 Tahun 2016 serta apa akibat hukum dengan adanya pembatasan tersebut.

\subsection{Rumusan Masalah}

1. Bagaimanakah pembatasan asas kebebasan berkontrak dalam Permen ATR Nomor 29 Tahun 2016?

2. Akibat hukum apakah yang dapat timbul atas pembatasan asas kebebasan berkontrak dalam Permen ATR Nomor 29 tahun 2016?

\subsection{Tujuan Penulisan}

1. Untuk mengetahui pembatasan asas kebebasan berkontrak dalam Permen ATR Nomor 29 Tahun 2016.

2. Untuk mengetahui akibat hukum apa yang dapat timbul atas pembatasan asas kebebasan berkontrak dalam Permen ATR Nomor 29 Tahun 2016.

\section{ISI}

\subsection{Metode Penelitian}

Menurut Soerjono Seokanto, penelitian hukum dapat dibagi menjadi dua tipologi yaitu Normatif dan Sosiologis atau empiris. ${ }^{2}$

Penelitian ini menggunakan metode penelitian hukum normatif. Seotandyo Wignyosobroto menyebut metode penelitian

${ }^{2}$ E. Saefullah Wiradipradja, 2016, Penuntun Praktis Metode Penelitian dan Penulisan Karya Ilmiah Hukum, Cet. 2, Keni Media, Bandung, h. 27. 
hukum normatif juga sebagai metode penelitian hukum doktrinal. Seotandyo juga berpandangan bahwa di Indonesia metode penelitian hukum doktrinal ini lazim disebut metode penelitian hukum normatif yang dilawankan dengan metode penelitian hukum empiris atau metode penelitian nondroktrinal. ${ }^{3}$ Penelitian hukum normatif merupakan penelitian dimana objek kajiannya merupakan dokumen peraturan perundang-undangan dan bahan-bahan pustaka. ${ }^{4}$ Dalam penelitian ini juga menggunakan pendekatan perundang-undangan yaitu dengan mengkaji peraturan Permen ATR Nomor 29 Tahun 2016 serta pasal 1338 Burgerlijk Wetboek (KUHPer).

\subsection{Hasil dan Analisis}

\subsubsection{Aturan yang Membatasi Asas Kebebasan Berkontrak Dalam Permen ATR Nomor 29 Tahun 2016}

Pasal 1313 Kitab Undang-Undang Hukum Perdata (yang selanjutnya disebut KUHPer) menguraikan bahwa persetujuan adalah perbuatan antara satu orang atau lebih yang mengikatkan dirinya dengan satu orang lain atau lebih. Dalam hal agar persetujuan tersebut dapat dikatakan sah maka harus memenuhi ketentuan sebagaimana diatur dalam Pasal 1320 KUHPer yakni:

1. Sepakat mereka yang mengikatkan dirinya;

2. Kecakapan untuk membuat suatu perikatan;

3. Suatu hal tertentu;

4. Suatu sebab yang halal.

Permen ATR Nomor 29 Tahun 2016 mengatur bahwa orang asing hanya bisa memperoleh tempat tinggal dengan Hak Pakai dan

3I Made Pasek Diantha, 2016, Metode Penelitian Hukum Normatif dalam Justifikasi Teori Hukum, Prenada Media Group, Jakarta, h. 93.

${ }^{4}$ Made Utami Jayanti, op.cit, h. 355. 
untuk mendapatkan Hak Pakai tersebut maka prosedur yang harus ditempuh adalah dengan pengalihan hak atas tanah yang dilakukan melalui kesepakatan antara orang asing dengan pihak lainnya yang memiliki tanah. Kesepakatan yang dibuat juga harus memenuhi ketentuan Pasal 1320 KUHPer di atas. Salah satu syarat objektif yang terdapat dalam pasal tersebut adalah adanya suatu hal tertentu yang berarti bahwa harus ada objek daripada perjanjian tersebut dan apabila merupakan suatu benda seperti rumah tunggal atau rumah susun maka harus diuraikan juga mengenai detail objek yang dimaksud termasuk harga transaksi dalam perjanjian jual beli yang disepakati atas objek tersebut.

Dalam membuat kesepakatan khususnya dalam hal perjanjian melekat pula asas umum dalam Hukum Perdata yakni asas kebebasan berkontrak. Perwujudan asas tersebut terdapat pada Pasal 1338 ayat (1) KUHPer yang mengatur bahwa persetujuan yang dibuat secara sah akan berlaku layaknya undang-undang bagi pembuatnya (Asas Pacta Sunt Servanda), kata "semua" berarti bahwa setiap subyek hukum dapat membuat perjanjian yang isinya tentang apapun, subyek hukum memiliki kebebasan untuk menentukan bentuk perjanjian ${ }^{5}$, selama hal tersebut juga dilaksanakan dengan iktikad baik atau yang oleh Hoge Raad istilahnya disamakan dengan kerasionalan dan kepatutan. ${ }^{6}$ Kontrak atau perjanjian dapat dibedakan menjadi dua macam fungsi, yaitu fungsi yuridis dan fungsi ekonomis. Fungsi yuridis yaitu untuk memberikan kepastian hukum bagi para pihak, sedangkan fungsi ekonomis yakni untuk menggerakkan (hak milik) sumber daya dari nilai penggunaan yang lebih rendah menjadi lebih

${ }^{5}$ Christiana Tri Budhayati, 2009, Asas Kebebasan Berkontrak Dalam Hukum Perjanjian Indonesia, Widya Sari Vol. 10 No. 3, h. 233.

6Ridwan Khairandy, 2017, Iktikad Baik Dalam Kontrak Di Berbagai Sistem Hukum, FH UII Press, Yogyakarta, h. 9. 
tinggi. ${ }^{7}$ Dengan asas kebebasan berkontrak maka setiap orang dapat dengan bebas membuat kontrak dengan siapa saja, menentukan isi kontrak dan bentuknya serta memilih hukum yang berlaku, 8 namun asas kebebasan berkontrak tersebut mendapat pembatasan apabila dikaitkan dengan Permen ATR Nomor 29 Tahun 2016. Pembatasan yang dimaksud bukan merupakan pembatasan terkait iktikad baik yang menurut KUHPer memang merupakan syarat agar suatu perjanjian dapat mengikat seperti undang-undang, akan tetapi pembatasan tersebut berkaitan dengan isi kontrak, khususnya mengenai harga transaksi. Para pihak khususnya bagi orang asing yang selain hanya dapat memperoleh hak pakai atas tempat tinggal yang merupakan unit baru juga tidak dapat semena-mena dalam menentukan harga transaksi daripada objek kesepakatan yang merupakan isi kontrak karena dalam Pasal 5 ayat (1) Permen ATR Nomor 29 Tahun 2016 diatur bahwa rumah tempat tinggal atau hunian yang dapat dimiliki oleh orang asing diberikan batasan harga minimal seperti tercantum dalam lampiran Permen tersebut sebagai bagian yang tidak terpisahkan dari Permen itu.

Apabila mengacu pada asas kebebasan berkontrak maka seharusnya isi daripada suatu kesepakatan termasuk mengenai penentuan harga sebuah objek adalah merupakan kebebasan dan tergantung pada kesepakatan para pihak dan seharusnya apa yang tercantum dalam perjanjian pengalihan hak atas tanah diantara para pihak juga sudah mencantumkan harga riil yang memang terjadi dalam kesepakatan tersebut, namun dengan adanya pembatasan dalam Perman tersebut, oleh karena itu ketika para

${ }^{7}$ Salim H.S., 2010, Perkembangan Hukum Kontrak Innominaat di Indonesia, Sinar Grafika, Jakarta, h. 35.

8Ridwan Khairandy, op.cit, h. 29. 
pihak yang termasuk orang asing membuat suatu perjanjian maka harga objek perjanjian harus sesuai dengan ketentuan yang berlaku, walaupun dalam Permen ATR Nomor 29 Tahun 2016 tidak diatur mengenai sanksi apabila ternyata orang asing membeli rumah tempat tinggal atau hunian di bawah harga minimum yang sudah ditetapkan.

\subsubsection{Akibat Hukum Yang Dapat Timbul Atas Pembatasan Asas Kebebasan Berkontrak Dalam Permen ATR Nomor 29 Tahun 2016}

Pembatasan terkait harga minimal dalam transaksi agar orang asing dapat memiliki tempat tinggal dengan Hak Pakai yang didapat dari orang lain yang memiliki rumah tinggal, dapat menimbulkan beberapa akibat hukum yang seharusnya tidak timbul dalam kesepakatan antara para pihak.

Rumah tempat tinggal atau hunian adalah salah satu objek kesepakatan. Pasal 1332 KUHPer menyebutkan bahwa "pokok perjanjian adalah barang yang dapat diperdagangkan" $"$, untuk itu rumah atau hunian bisa juga disebut sebagai pokok perjanjian karena memiliki nilai jual sehingga dapat diperdagangkan. Adanya pembatasan harga minimal transaksi dapat mengakibatkan ketidakbebasan bagi para pihak dalam menentukan harga yang sebenarnya disepakati pada rumah tempat tinggal atau hunian yang merupakan objek kesepakatan dan pokok perjanjian.

Dalam membuat perjanjian seharusnya ditulis hal-hal yang memang menjadi kesepakatan para pihak, namun dengan adanya pembatasan harga minimal ini maka dapat timbul akibat hukum

9I Ketut Artadi dan I Dewa Nyoman Rai Asmara Putra, 2014, Implementasi Ketentuan-Ketentuan Hukum Perjanjian Kedalam Perancangan Kontrak, Udayana University Press, Denpasar, h. 33. 
yang terjadi akibat adanya pembatasan yang menyebabkan ketidakbebasan bagi para pihak untuk menentukan harga transaksi sehingga dapat membuat mereka memilih untuk tidak mencantumkan harga transaksi yang sebenarnya, semata-mata agar tidak menyalahi aturan dan apabila itu terjadi maka akan merugikan mereka sendiri karena ketika dikemudian hari terdapat suatu permasalahan terkait harga riil yang disepakati oleh para pihak maka mereka tidak akan mendapatkan perlindungan hukum.

Perlakuan pembatasan harga tersebut juga dapat menimbulkan terjadinya penyelundupan hukum, dimana antara orang asing sebagai pihak yang ingin mendapatkan hak pakai atas rumah tempat tinggal atau hunian dengan pihak yang memberikan hak tersebut mengambil cara mudah yang sifatnya sebagai penyamaran dengan maksud untuk mendapatkan kembali kebebasan mereka dalam menentukan isi perjanjian yaitu harga transaksi terhadap suatu objek, seperti misalnya dengan memalsukan harga transaksi yang sudah dijabarkan sebelumnya atau hingga melakukan perbuatan nominee agar mempermudah proses transaksi. Nominee adalah perbuatan dimana WNI sebagai subyek yang berhak memperoleh hak milik atas tanah meminjamkan namanya kepada subyek yang tidak diberikan hak yaitu WNA agar dapat memiliki tanah secara hak milik ${ }^{10}$, perbuatan tersebut adalah bentuk penyelundupan hukum yang melanggar aturan. ${ }^{11}$ Perbuatan Nominee mereka tempuh karena dalam nominee para pihak dalam suatu perjanjian merupakan WNI

10I Dewa Agung Dharma Jastrawan \& I Nyoman Suyatna, 2019, Keabsahan Perjanjian Pinjam Nama (Nominee) Oleh Warga Negara Asing Dalam Penguasaan Hak Milik Atas Tanah di Indonesia, Kertha Semaya Vol. 07 No. 01, h. 6.

${ }^{11}$ Ibid, h. 7. 
sehingga pembatasan harga minimal pengalihan hak pakai bagi orang asing tidak akan berlaku.

Apabila kemungkinan-kemungkinan tersebut terjadi maka akan timbul penafsiran adanya iktikad tidak baik dalam membuat perjanjian bagi para pihak yang di dalamnya termasuk orang asing yang mengakibatkan perjanjian tersebut tidak dapat mengikat para pihak karena Pasal 1338 KUHPer menjelaskan bahwa asas pacta sunt servanda yaitu asas dimana hakim atau pihak ketiga wajib menghormati isi perjanjian yang dibuat oleh para pihak layaknya undang-undang ${ }^{12}$ akan berlaku apabila perjanjian tersebut dilaksanakan dengan iktikad baik.

Selain itu, penyamaran harga transaksi dalam perjanjian jual beli rumah atau hunian juga dapat menyebabkan kerugian bagi masyarakat khususnya pihak-pihak yang merupakan penjual maupun pembeli karena kewajiban pajak baik Pajak Penghasilan (PPh) untuk penjual maupun Bea Perolehan Hak atas Tanah dan Bangunan (BPHTB) yang merupakan pajak yang dibebankan terhadap perolehan hak atas tanah atau bangunan ${ }^{13}$ sebagai kewajiban pembeli, keduanya dapat menjadi lebih tinggi daripada yang seharusnya menjadi kewajiban mereka. Negara pun dapat dirugikan dalam hal ini apabila para pihak mencantumkan harga lebih rendah daripada harga riil namun tidak kurang dari batas harga minimal transaksi yang menyebabkan baik PPh maupun BPHTB menjadi lebih rendah sehingga pemasukan negara berkurang dari yang seharusnya didapat. Hal-hal tersebut terjadi apabila pihak penjual menaikan atau menurunkan harga transaksi dalam perjanjian namun tidak sesuai dengan apa yang dibayarkan

${ }^{12}$ Salim H.S., op.cit, h. 10.

${ }^{13}$ Zaeni Asyhadie, 2014, Hukum Bisnis: Prinsip dan Pelaksanaannya di Indonesia, Rajawali Pers, Jakarta, h. 294. 
oleh pembeli, karena kalaupun harus mencantumkan harga yang sebenarnya akan menjadi permasalahan tersendiri, karena akan menemui kesulitan mendapatkan objek dengan harga yang tepat seperti ketentuan dalam Permen ATR Nomor 29 Tahun 2016 yang sesuai dengan kondisi, lokasi maupun faktor-faktor pendukung lainnya yang menjadi alasan bagi orang asing menjatuhkan pilihannya pada objek yang bersangkutan.

Penyelundupan hukum menyebabkan lemahnya perlindungan hukum terhadap para pihak pembuat perjanjian terkait pengalihan hak pakai kepada orang asing. Orang asing yang menetap di Indonesia yang tidak mendapatkan perlindungan hukum yang baik dapat menjadi ragu hingga membatalkan niatnya untuk berinvestasi di Indonesia dan menjadi tidak betah yang kemudian memilih untuk kembali ke negara asal atau pindah ke negara lain. Kondisi ini tentu akan merugikan Indonesia karena masuknya pihak asing secara otomatis akan mendukung pertumbuhan ekonomi serta meningkatkan pemasukan pada keuangan negara karena dengan demikian, jumlah dana atau modal yang masuk ke kantong pemerintah otomatis akan signifikan jumlahnya. Karena akan ada capital inflow. ${ }^{14}$

\section{PENUTUP}

\subsection{KESIMPULAN}

1. Asas kebebasan berkontrak dalam perjanjian jual beli antara para pihak yang termasuk WNA mendapat pembatasan dalam Permen ATR Nomor 29 Tahun 2016. Pembatasan yang dimaksud bukan merupakan pembatasan terkait iktikad baik yang menurut KUHPer memang merupakan syarat agar suatu

${ }^{14}$ Adrian Sutedi, 2012, Hukum Rumah Susun \& Apartemen, Sinar Grafika, Jakarta, h. 338. 
perjanjian dapat mengikat seperti undang-undang, akan tetapi pembatasan tersebut berkaitan dengan isi kontrak, khususnya mengenai harga transaksi. Para pihak yang termasuk orang asing di dalamnya tidak dapat semena-mena dalam menentukan harga daripada objek kesepakatan yang merupakan isi kontrak karena dalam Pasal 5 ayat (1) Permen ATR Nomor 29 Tahun 2016 diatur bahwa rumah tempat tinggal atau hunian yang dapat dimiliki oleh orang asing diberikan batasan harga minimal seperti yang tercantum dalam lampiran Permen tersebut.

2. Pembatasan harga minimal transaksi jual beli hak pakai atas rumah tempat tinggal atau hunian menimbulkan beberapa akibat hukum yang seharusnya tidak timbul dalam kesepakatan antara para pihak. Pembatasan tersebut dapat menimbulkan terjadinya penyelundupan hukum karena para pihak yaitu penjual dan pembeli bisa mengambil cara mudah yang sifatnya sebagai penyamaran, seperti misalnya dengan memalsukan harga transaksi yang sebenarnya dengan yang tercantum dalam perjanjian atau hingga melakukan perbuatan nominee agar mempermudah proses transaksi yang menyebabkan kerugian baik bagi masyarakat maupun negara. Selain itu, penyelundupan hukum dapat membuat timbulnya penafsiran adanya iktikad tidak baik diantara para pihak yang malah akan merugikan mereka sendiri.

\subsection{SARAN}

Pembatasan harga transaksi pengalihan hak pakai terhadap suatu rumah tempat tinggal atau hunian bagi WNA selain dapat memberikan kepastian hukum juga dapat menimbulkan akibat hukum yang dapat merugikan masyarakat dan negara, untuk 
mengantisipasi hal tersebut maka pemerintah perlu melakukan pengkajian lebih dalam mengenai dampak negatif yang timbul dari adanya pembatasan harga tersebut serta perlu mencantumkan sanksi apabila terjadi pelanggaran terhadap aturan terkait pembatasan harga tersebut.

\section{DAFTAR PUSTAKA}

\section{BUKU}

Artadi, Ketut dan Asmara Putra, I Dewa Nyoman Rai, 2014, Implementasi Ketentuan-Ketentuan Hukum Perjanjian Kedalam Perancangan Kontrak, Udayana University Press, Denpasar.

Asyhadie, Zaeni, 2014, Hukum Bisnis: Prinsip dan Pelaksanaannya di Indonesia, Rajawali Pers, Jakarta.

Diantha, I Made Pasek, 2016, Metode Penelitian Hukum Normatif dalam Justifikasi Teori Hukum, Prenada Media Group, Jakarta.

Khairandy, Ridwan, 2017, Iktikad Baik Dalam Kontrak Di Berbagai Sistem Hukum, FH UII Press, Yogyakarta.

Salim, H.S, 2010, Perkembangan Hukum Kontrak Innominaat di Indonesia, Sinar Grafika, Jakarta.

Sutedi, Adrian, 2012, Hukum Rumah Susun \& Apartemen, Sinar Grafika, Jakarta.

Wiradipradja, E. Saefullah, 2016, Penuntun Praktis Metode Penelitian dan Penulisan Karya Ilmiah Hukum, Cet. 2, Keni Media, Bandung.

\section{JURNAL}

Budhayanti, Christiana Tri, 2009, Asas Kebebasan Berkontrak Dalam Hukum Perjanjian Indonesia, Widya Sari Vol. 10 No. 3.

Jastrawan, I Dewa Agung Dharma \& Suyatna, I Nyoman, 2019, Keabsahan Perjanjian Pinjam Nama (Nominee) Oleh Warga Negara Asing Dalam Penguasaan Hak Milik Atas Tanah di Indonesia, Kertha Semaya Vol. 07 No. 01.

Jayanti, Made Utami, 2018, Pengaturan Perjanjian Pengikatan Jual Beli Atas Rumah Tempat Tinggal Oleh Warga Negara Asing Dengan Berlakunya Peraturan Menteri Agraria Dan Tata Ruang Nomor 29 Tahun 2016, Acta Comitas Vol. 3 No. 2. 


\section{PERATURAN PERUNDANG-UNDANGAN}

Burgerlijk Wetboek [Kitab Undang-Undang Hukum Perdata], terjemahan Subekti dan R. Tjitrosudibio.

Undang-Undang Republik Indonesia Nomor 11 Tahun 2005 Tentang Pengesahan International Covenant On Economic, Social And Cultural Rights (Kovenan Internasional Tentang Hak-Hak Ekonomi, Sosial Dan Budaya).

Peraturan Pemerintah Republik Indonesia Nomor 103 Tahun 2015 Tentang Pemilikan Rumah Tempat Tinggal Atau Hunian Oleh Orang Asing Yang Berkedudukan Di Indonesia.

Peraturan Menteri Agraria dan Tata Ruang/Kepala Badan Pertanahan Nasional Republik Indonesia Nomor 29 Tahun 2016 Tentang Tata Cara Pemberian, Pelepasan, Atau Pengalihan Hak Atas Pemilikan Rumah Tempat Tinggal Atau Hunian Oleh Orang Asing Yang Berkedudukan Di Indonesia. 